\title{
Fuzzy performance Evaluation in Romanian Banking Industry
}

\author{
Simona RUS ${ }^{1+}$ \\ ${ }^{1}$ Politehnica University of Timisoara, Faculty of Management in Production and Transportation, Department \\ of Management, 14 Remus Street, Timisoara, 300191, Romania
}

\begin{abstract}
The banking system contributes to economic stability. The banking system stability can be a pillar for the overall macroeconomic stability of the country. The main objective of this paper is to present the importance of information technology and fuzzy logic for the analysis and development of the banking industry in Romania. An evaluation of the literature suggests that the number of publications using multicriteria and fuzzy decision-making methods is increasing from one year to the next. The use of FAHP and FTOPSIS methods in assessing banks performance contributes to increasing the competitiveness of banks and developing future competitive strategies. Five Romanian banks are evaluated, based on five established criteria. The banks were selected according to the profit recorded in 2017. The results highlight that financial and non-financial indicators contribute to the increasing of banking competitiveness.
\end{abstract}

Keywords: banking sector, fuzzy, AHP, TOPSIS, competitiveness.

\section{Introduction}

The lack of competition was due to regulations adopted by several countries after the economic crisis of 1930. After 1980, financial liberalization and technological evolution were important factors in increasing banking competition [1].

The performance must be understood as a concept that contributes determine the outputs from a process. Those are the result of some planned and intentional activities made in the evaluated organisation. These outputs are constituted in form of some indicators that contribute to the achievement of organizational goals and sustainable development. Sustainable organization development refers to a long period. The performance can be seen as a general evaluation of all the organization efforts in achieving the proposed goals. Increasing performance is realized in tight bond with the organization's capacity to develop and adapt to new techniques and methods appeared in the field of activity. The proposed goals are established according to organization vision and mission. Banks performance evaluation are very important for stakeholders because it determines banks capabilities to compete in this sector and to became competitive in this industry. Also this evaluation has a critique importance for sector development. The purpose of this study is to propose a fuzzy multi criteria decision model to evaluate banks performance. Are examined the seven biggest commercial banks from Romanian banking sector, and these banks are evaluated according to several variables of competitiveness [2]. The Fuzzy Analytical Hierarchy Process and the technique for orders performance by the similarity method with the ideal solution (TOPSIS) are integrated in the proposed model. Using FAHP the proposed criteria for analysis are hierarchized, and using TOPSIS the alternatives considered are hierarchized. Depending on the weights of the criteria based on experts opinions by application FAHP method banks are classified. The weights obtained in FAHP represent inputs for TOPSIS method. The results show that not only the financial performance contributes to increasing the banking system competitiveness but also a series of non-financial factors. Throughout the whole evaluation process the judgment of five

\footnotetext{
${ }^{+}$Corresponding author.

E-mail address: simona_rus@yahoo.com
} 
experts from the banking industry were used, selected from different banks (with different financial results) [3].

\section{The Importance of Information Technology in the Banking Sector}

The use of information technology $(\mathrm{T})$ in banking system is very important and is a requirement of this industry. IT contributes to rising the competition and developing some innovative products and services [4]. Nowadays, IT contributes changing the relationship with the customer. Technology hasn't reinvented the banking process, but has contributed to develop superior products and services. It's perceived by most customers as a instrument for decreasing the costs and for communication with customers [5]. IT offers banks the possibility to compete in this banking industry. It also offers the necessary framework to face the competitive challenges. Information technology allows developing some competitive products adapted to customers' wishes of every age. Using this instrument provides a better market infrastructure. Speaking of risks control, IT contributes to the implementation of reliable techniques for controlling them [3]. The internet has significantly influenced banks distribution channels. The internet and smartphone have become important tools in the design, development and placement of banking products and services [1]. The most important benefits of IT in banking industry were previously presented. From the perspective of barriers that develop through IT usage, there are some reluctances from customers. Therefore, these barriers should be treated by banks, and those products and services should be redesigned [6].

\section{Applying AHP and TOPSIS to the Banking System}

The Analytical Hierarchy Process -AHP was introduced by Thomas Saaty in 1980 (Saaty, 1980) and is an effective tool used to make complex decisions and contributes to prioritization and selection of a favorable decision. By reducing complex decisions to a series of pair comparisons and then synthesizing results, AHP contributes to capturing both subjective and objective aspects. Initially, it was developed to resolve limited resource allocation and planning needs within the army. Since its introduction, AHP has become one of the most widely used MADM methods and has been used to resolve unstructured issues in different areas of human needs and interests such as political, economic, social, and management sciences [7].

The fuzzy method TOPSIS was first proposed by Hwang and Yoon [8]. This method has been proposed to solve multi-attribute decision-making (MADM) problems by using the optimal solution concept. The TOPSIS algorithm considers both the ideal solution and the ideal negative solution that is used to determine the optimal solution to a multi-objective decision-making (MODM) problem [1].

In today's competitive economic environment, an adequate assessment of companies' performance is very important not only for the organization but also for its creditors and investors [5]. Evaluation is one of the most important tools for identifying strengths and weaknesses in the internal market and for identifying external opportunities and threats and identifying the position of other companies [9]. These assessments can be used to identify opportunities and keep banks in business. AHP and FAHP methods are used in practical approaches to weighting criteria and subcriptions [7].

Fuzzy AHP approaches are used to determine the weights of different criteria. In decision-making with multiple criteria, decision-makers choose linguistic variables rather than present their judgments as precise values. Therefore, the theory of fuzzy sets is applicable in this respect. The theory of fuzzy sets is a useful means to treat imprecise and vague data [10]. So the result is close to the real situation and contributes to the decisions taken within the organization.

Among the methods developed to solve multi-criteria issues, the fuzzy AHP method has been widely applied in recent research to solve various problems. [6] uses FAHP to compare the performance of food companies in Turkey. [11] applied AHP technology to classify Saudi industry technologies. [12] also incorporated the Geographic Information System (GIS) and FAHP to address the issue of landfill selection and to develop the assessment of the potential for waste disposal.

Inventory of solutions presented in the literature, [11], [13], [14], [15], [16], MCDM is presented in Table 1 for various industries and in [17], [18], [19] for the banking system. 
Table 1: Application of fuzzy AHP and TOPSIS in the development of business solutions

\begin{tabular}{|c|c|c|c|c|c|c|}
\hline Application & Authors & Alternative & Selected criteria & Problem & $\begin{array}{l}\text { Techniques } \\
\text { used }\end{array}$ & $\begin{array}{l}\text { Selected } \\
\text { alternative }\end{array}$ \\
\hline $\begin{array}{l}\text { Planning a } \\
\text { location for } \\
\text { the urban } \\
\text { distribution } \\
\text { center (under } \\
\text { uncertainty) }\end{array}$ & $\begin{array}{l}\text { (Awasthia, } \\
\text { Chauhanb, } \\
\text { \& Goyal) }\end{array}$ & $\begin{array}{l}3 \text { different } \\
\text { locations: } \\
\mathrm{A}, \mathrm{B} \text { and } \mathrm{C}\end{array}$ & $\begin{array}{l}\text { 1.Accessibility } \\
\text { 2.Security } \\
\text { 3.Connectivity with } \\
\text { multimodal transport } \\
\text { 4.Costs } \\
\text { 5.Impact on the } \\
\text { environment, } \\
\text { 6.The proximity to } \\
\text { customers, } \\
\text { 7.Proximity to } \\
\text { suppliers } \\
\text { 8. Availability of } \\
\text { resources }\end{array}$ & $\begin{array}{l}\text { Planning location } \\
\text { for urban } \\
\text { distribution center } \\
\text { is key to reducing } \\
\text { distribution costs } \\
\text { and reduce traffic } \\
\text { congestion caused } \\
\text { by the movement } \\
\text { of goods in urban } \\
\text { areas. }\end{array}$ & TOPSIS & $\begin{array}{l}\text { A1 }>\text { A3>A } \\
2 . \\
\text { It was } \\
\text { selected } \\
\text { the best } \\
\text { option, } \\
\text { option A1 }\end{array}$ \\
\hline $\begin{array}{l}\text { MCDM } \\
\text { approach to } \\
\text { clothing }\end{array}$ & $\begin{array}{l}\text { (Ding, Hu, } \\
\& \text { Zhang, } \\
\text { 2011) }\end{array}$ & $\begin{array}{l}65 \text { models } \\
\text { are studied } \\
\text { pants with } \\
\text { the same } \\
\text { color, style } \\
\text { and } \\
\text { material for } \\
\text { women }\end{array}$ & $\begin{array}{l}\text { 1. The waist size } \\
\text { (W), 2. the hip } \\
\text { circumference (H) } \\
\text { and 3. the length of } \\
\text { the trousers (L) }\end{array}$ & $\begin{array}{l}\text { Solving large- } \\
\text { scale size } \\
\text { matching in order } \\
\text { to be able to } \\
\text { market these } \\
\text { products online }\end{array}$ & $\begin{array}{l}\text { Different } \\
\text { methods } \\
\text { for } \\
\text { selection }\end{array}$ & $\begin{array}{l}\text { Products } \\
\text { that meet } \\
\text { customer } \\
\text { requiremen } \\
\text { ts }\end{array}$ \\
\hline $\begin{array}{l}\text { Environmenta } \\
1 \text { risk } \\
\text { assessment }\end{array}$ & $\begin{array}{l}\text { (Rezaian, } \\
\text { 2012) }\end{array}$ & $\begin{array}{l}\text { Thermal } \\
\text { station } \\
\text { Location } 1 \\
\text { Location } 2 \\
\text { Location } 3\end{array}$ & $\begin{array}{l}\text { 1.The operation of } \\
\text { the power plant } \\
\text { 2. Health safety risks } \\
\text { 3. Technological, } \\
\text { 4. Risks affected by } \\
\text { the environment }\end{array}$ & $\begin{array}{l}\text { Finding the best } \\
\text { location for } \\
\text { building the plant }\end{array}$ & AHP & $\begin{array}{l}\text { The best } \\
\text { location is } \\
\text { location } 3\end{array}$ \\
\hline $\begin{array}{l}\text { Satisfaction of } \\
\text { customers and } \\
\text { profit growth }\end{array}$ & $\begin{array}{l}\text { (Medjoudj, } \\
\text { 2013) }\end{array}$ & $\begin{array}{l}\mathrm{A} 1, \mathrm{~A} 2, \mathrm{~A} 3 \\
\text { și A4 }\end{array}$ & $\begin{array}{l}\text { Cost, reliability, } \\
\text { availability and } \\
\text { energy quality }\end{array}$ & $\begin{array}{lr}\text { Investigate } & \text { the } \\
\text { appropriate } & \text { tools } \\
\text { to reach the } \\
\text { objectives }\end{array}$ & AHP & $\begin{array}{l}\text { The best } \\
\text { variant is } \\
\text { variant } \mathrm{A} 2\end{array}$ \\
\hline
\end{tabular}

It can be noticed that the fuzzy method AHP and TOPSIS is used in the business environment and in banks for various development actions.

\section{Applying the Fuzzy AHP and TOPSIS Method to the Romanian Banks}

After conducting a market research we have established a set of criteria that contribute to performance evaluation Romanian banking system. Based on the judgment of bank experts in Romania, the hierarchy in Table 2 was obtained.

Table 2: Important criteria for assessing bank performance

\begin{tabular}{|c|c|c|}
\hline Criteria & Criteria weight & Rank \\
\hline Banking network & 0,38 & 1 \\
\hline Sustainable development & 0,34 & 2 \\
\hline Credit products & 0,13 & 5 \\
\hline Innovation & 0,18 & 4 \\
\hline E-banking products & 0,31 & 3 \\
\hline
\end{tabular}

In order to classify the first five banks, existing in the classification made according to the profit realised in 2017, which we will note them generically with B1, B2, B3, B4 and B5, the weights obtained in Table 2 
were used. By using TOPSIS, the five banks in Romania are hierarchized according to the judgement of experts in the field. The profit situation of the five banks for the years 2016 and 2017 is presented in Table 3.

Table 3: Profit of the first five banks in the years 2016 and 2017

\begin{tabular}{|c|c|c|}
\hline Bank & Profit 2017 (billions euro) & Profit 2016 (billions euro) \\
\hline B1 & 0,293 & 0,16 \\
\hline B2 & 0,25 & 0,26 \\
\hline B3 & 0,14 & 0,22 \\
\hline B4 & 0,11 & 0,09 \\
\hline B5 & 0,10 & 0,089 \\
\hline
\end{tabular}

Following TOPSIS method, the hierarchizing of the five banks places B2 on the first position, B1 on the second position, $\mathbf{B 5}$ on the fourth position and B4 on the third position. Bank B3 is placed on place five. Bank B4 is the most technologically advanced considering the existing assessments, that's why it received a higher score from experts than previous ones. The first bank, even if it has stable financial indicators, for non-financial indicators the experts appreciated this bank as less innovative and technologized. It can be said that both financial, as well non-financial indicators contribute to increasing banks performance, and this factors must be permanently considered and developed.

\section{Acknowledgements}

This work was supported by a mobility grant of the Romanian Ministery of Research and Innovation, CNCS - UEFISCDI, project number PN-III-P1-1.1-MC2018-0579, within PNCDI III.

\section{Conclusions}

In this study, AHP and TOPSIS multicriteria methods were used to assess the performance of five banks in Romania. For appreciation the Saaty scale was used, so the fuzzy triangular numbers were used. The study will contribute to the advancement of the literature because presents an evaluation of the first five banks following the economic-financial crisis from 2008. It is a beneficial evaluation for investors who have to make investment decisions on this sector of activity. For future studies, the performance of different decision-making approaches with several fuzzy criteria can be compared to highlight their degree of truth.

\section{References}

[1] Tzeng, G., \& Huang, J. J. (2011). Multiple Attribute Decision Making: Methods and Applications. New York: Taylor \& Francis.

[2] Ivascu, L., Cirjaliu, B., \& Draghici, A. (2015a). Business model for the university-industry collaboration in open innovation. 3rd Global Conference on Business, Economics, Management and Tourism, vol. 39, 674-678, Italy.

[3] Cuong, D., Hien, H., \& Long, T. (2018). Multi-Criteria Decision-Making Model Evaluating the Performance of Vietnamese Commercial Banks. International Journal of Financial Research 9(1).

[4] Ivascu, L., \& Cioca, L.I. (2015b). From Theory to Practice: Evolution of Sustainable Development in Organizations. 25th International-Business-Information-Management-Association Conference, vol. I-VI, 725-733, Netherlands.

[5] Izvercian, M., Radu, A., Ivascu, L., \& Ardelean B.O. (2013). The Impact of Human Resources and Total Quality Management on the Enterprise. 12th International Symposium in Management, 124, 27-33, Romania.

[6] Kabak, M., Serhat , B., \& Yigit, K. (2012). A fuzzy hybrid MCDM approach for professional selection. Expert Systems with Applications 39(3), 3516-3525.

[7] Wang, Y., \& Xia, Q. (2009). Fuzzy AHP and BSC approach for evaluating performance of a software company based on knowledge management. Proceedings of the IEEE 2009 First International Conference on Information, 242-2245. Nanjing, China. 
[8] Hwang, C., \& Yoon, K. (1981). Lecture notes in economics and mathematical systems. In Multiple Attribute Decision Making: Methods and Applications, 166-186.

[9] Rebai, S., Naceur Azaiezb, M., \& Saidanec, D. (2016). A multi-attribute utility model for generating a sustainability index in the banking sector. Journal of Cleaner Production, 131(1), 835-849.

[10] Zadeh, A. (2015). Fuzzy logic - a personal perspective. Fuzzy Sets and Systems, 281, 4-20.

[11] Al-Ahmari, A. (2008). Evaluation of CIM technologies in Saudi industries using AHP. International Journal of Advanced Manufacturing Technology 34(7-8), 736-747.

[12] Akbari, V., \& și colab. (2008). Landfill site selection by combining GIS and fuzzy multi-criteria decision analysis case study: Bandar Abbas. World Applied Sciences, 3(1), 39-47.

[13] Balali V., B. Z. (2010). electing appropriate structural system: Application of PROMETHEE decision making method. 2nd International Conference on Engineering Systems Management and Its Applications (ICESMA), (pg. 1-6). Sharjah, UAE.

[14] Balali V., A. M. (2014). Selection of Appropriate Material, Construction Technique, and Structural System of Bridges by Use of Multi-Criteria Decision-Making Method,. Journal of the Transportation Research Board (TRR) (2431), 79-87.

[15] Carlsson, C., FEdrizzi, M., \& Fuller, R. (2004). Fuzzy Logic in Management. Finalnda: Springer.

[16] Ferreira Luciano, D. B. (2018). A fuzzy hybrid integrated framework for portfolio optimization in private banking. Expert Systems with Applications vol. 92, 350-362.

[17] Cuong, D., Hien, H., \& Long, T. (2018). Multi-Criteria Decision-Making Model Evaluating the Performance of Vietnamese Commercial Banks. International Journal of Financial Research 9(1).

[18] Akkoc, S., \& Vatansever, K. (2013). Fuzzy Performance Evaluation with AHP and Topsis Methods: Evidence from Turkish Banking Sector after the Global Financial Crisis. Eurasian Journal of Business and Economics 6(11), 53-74.

[19] Saaty, T. (1980). The Analytic Hierarchy Process. New York: McGraw-Hill. 